\title{
Influence of gestation length, seasonality, and calf sex on birth weight and placental retention in crossbred dairy cows
}

\section{Influência da duração da gestação, estação do ano, sexo e peso ao nascer do bezerro sobre a retenção placentária em vacas leiteiras mestiças}

\author{
Estevão Vieira Rezende ${ }^{*}$ (D), Igor José Reis² (D) , Carla Cristian Campos ${ }^{1}$ (D) , Ricarda Maria \\ Santos $^{1}$
}

'Universidade Federal de Uberlândia, Uberlândia, MG, Brazil.

${ }^{2}$ Centro universitário de Patos de Minas, Patos de Minas, MG, Brazil.

${ }^{*}$ Correspondent-estevaovr@hotmail.com

Section: Medicina Veterinária

Received

May 7, 2018

Accepted

November 19, 2019

Published

March 13, 2020

www.revistas.ufg.br/vet visit the website to get the how to cite in the article page.

\begin{abstract}
The objective of this study was to evaluate the influence of gestation length, season at calving (autumn-winter vs. spring-summer) and calf sex on birth weight and incidence of retained placenta (RP) in crossbred lactating dairy cows. A total of 187 parturitions were evaluated in a commercial dairy farm at Alto Paranaiba region, Minas Gerais, Brazil. Cows that did not release the placental membranes within the first 12 hours after calf expulsion were diagnosed with RP. At birth, calf sex was registered, and birth weight was estimated by using a weighing tape. The incidence of RP was 36.89\% (69/187). The mean birth weight of the calves $(41.73 \mathrm{~kg}) \mathrm{did}$ not differ among the calf sexes and seasons of the year at birth $(P>0.05)$, but the cows with below-average gestation lengths (274.4 days) calved lighter calves. Furthermore, the season of the year at calving and calf sex had no influence on RP incidence $(P>0.05)$, although a higher incidence of RP was observed in cows that had shorter gestation lengths (49.44\%) and calves below-average birth weights (51.76\%). In conclusion, cows with shorter gestation lengths produce lighter offspring and have a high predisposition to RP.
\end{abstract}

Keywords: dairy cattle, tropical region, transition period, diseases

\section{Resumo}

Objetivou-se avaliar a influência da duração da gestação, da estação do ano ao parto (outono-inverno vs. primaveraverão) e do sexo do bezerro sobre o peso ao nascimento, bem como os efeitos destas variáveis sobre a incidência de retenção de placenta (RP) em vacas leiteiras mestiças. Foram avaliados 187 partos em uma fazenda comercial leiteira na região do Alto Paranaíba, Minas Gerais, Brasil. Vacas que não liberaram os anexos placentários nas primeiras 12 horas após a expulsão do feto foram diagnosticadas com RP. Ao parto, o sexo da cria foi registrado e o peso ao nascer foi obtido por meio da fita de pesagem. A incidência de RP foi de $36,89 \%$ (69/187). O peso médio ao nascer dos bezerros $(41,73 \mathrm{~kg})$ não diferiu entre sexo e estação do ano ao nascimento $(P>0,05)$, porém vacas cuja gestação teve duração abaixo da média (274,4 dias) pariram bezerros mais leves. A estação do ano 
ao parto e o sexo da cria também não influenciaram a incidência de RP ( $P>0,05)$, no entanto uma maior incidência de RP foi observada em vacas que apresentaram gestações de menor duração $(49,44 \%)$ e cujas crias tiveram peso ao nascer abaixo da média $(51,76 \%)$. Concluise que vacas com período de gestação curto comprometem o peso ao nascer dos bezerros e são mais susceptíveis à desenvolver retenção de placenta.

Palavras-chave: bovinos leiteiros, gestação, região tropical, doenças

\section{Introduction}

Retained placenta (RP) is a uterine disease that occurs in the postpartum period and affects cows more frequently than other animal species. Among bovines, RP is more common in dairy cows ${ }^{(1)}$. Bovines have cotyledonary placenta, composed of maternal caruncles and fetal cotyledons, which produce 70 to 120 placentomes. Fetal membranes are strongly adhered to the uterus by the juxtaposition of chorionic villi to the uterus during pregnancy, allowing metabolic exchange between the mother and fetus(1).

$\mathrm{RP}$ is considered pathological when some or all fetal membranes are not released within the first 12 to 16 hours after fetal expulsion ${ }^{(2)}$, these membranes remain attached to the uterus or fail to externalize through the female genital tract. The placental release process involves the loss of maternal-fetal adhesion that occurs after the complete maturation of the placentome, and is correlated with the reduction of cellular population in the fetal and maternal tissues ${ }^{(3)}$. The immaturity of the placentomes causes edema in the chorionic villi, which is associated with hyperemia, necrosis, and a placental inflammatory process. Over time, the whole placental tissue undergoes autolysis and gradual decomposition and becomes friable with a yellow-brown coloration and fetid odor $^{(4)}$.

Twin birth, calving assistance, dystocia, stillbirth, abortion, and metabolic diseases are considered predisposing factors for RP occurrence ${ }^{(5,6)}$. In addition, the mechanical factors associated with dystocia, nutritional deficiency, infectious diseases, and poor management of stress and the animal's environment are involved in $\mathrm{RP}\left({ }^{(7)}\right.$. Poor animal management at the end of the gestation period usually causes an increased number of RP cases $^{(8)}$.

RP causes severe economic losses, particularly in dairy herds, including reduced milk production, increased costs related to veterinary services and treatments, discard of milk and involuntary culling, increased calving interval, and lower reproductive performance in dairy herds ${ }^{(4,9)}$.

The objective of this study was to evaluate the influence of gestation length (above or below average), season at calving (autumn-winter vs. spring-summer) and calf sex on its birth weight and RP incidence in crossbred lactating dairy cows. 


\section{Materials and methods}

This study was approved by the Animal Research Ethics Committee of the Patos de Minas University Center (UNIPAM) under the protocol \#24/17.

The data were collected from 2014 to 2016 in a commercial dairy farm located in Alto Paranaíba region, Minas Gerais State, Brazil. The herd, composed of crossbred dairy cows whose genetic composition varied from 3/4 Holstein to 1/4 Gir and 7/8 Holstein and 1/8 Gir, had an average of 130 lactating cows mechanically milked twice a day with an average milk production of $19.00 \mathrm{~L}$ per cow per day. The animals were dried-off 60 days before the expected date for calving and 30 days after dry-off, the pregnant cows were moved to a pre-calving pen, and were supplied a specific diet.

The lactating dairy cows were kept in a semi-intensive system, with rotational grazing patterns in paddocks of tropical pasture supplemented with a concentrate during the rainy season (spring-summer extending from November to March). During the dry period (autumn-winter extending from April to October), the cows were loosed house and supplied a total mixed ration (TMR) composed of corn silage concentrated according to milk production, water and minerals ad libitum.

The animals had free access to pasture. The farm did not have a temperature and humidity control system to minimize heat stress during the study.

The farm adopted a vaccination calendar, which included vaccines for foot-and-mouth disease, brucellosis, bovine viral diarrhea virus (BVD), infectious bovine rhinotracheitis (IBR), leptospirosis and clostridial vaccines. The animals were also dewormed twice a year, with an alternation of the used drugs. Cows were treated with bovine somatotropin (bST) during lactation from 60 days in milk (DEL) until 190 days of pregnancy, with an interval of 14 days between treatments.

Gestation length was determined as the interval between the day of the artificial insemination (Al) that resulted in pregnancy and the day of calving. Twin birth, stillbirth and/or abortions were not considered for this study. Data related to the calving of a single and viable calf, including the date of birth, season of the year at birth (springsummer or autumn-winter), calf sex and birth weight were registered. Calf weight was estimated using a weighing tape (Bovite $c^{\circledR}$ ); each calf was placed in a quadrupedal position and thoracic perimeter was encircled by a weighting tape positioned tightly behind the scapula.

To diagnose RP, cows were evaluated immediately after calving and, when possible, during calving, and those that did not release the placental membranes within the first 12 hours after fetus expulsion were considered as positive cases of RP. The occurrence of other postpartum diseases occurrences was not evaluated in this study.

Binomial variables were analyzed by logistic regression and continuous variables were assessed through the analysis of variance using the MINITAB software. The variables included in the model were birth weight adjusted in categories (below or above average), gestation length adjusted in categories (below or above average), calf sex, calving 
season (spring-summer or autumn-winter), and the possible interactions between these variables. Statistical significance was established as $P \leq 0.05$ and tendency as 0.05 $<\mathrm{P}<0.10$.

\section{Results and discussion}

In the present study, the average gestation length was 274.4 days, which is consistent with the gestation length of Holstein dairy cows ( $276 \pm 6$ days) reported by Vieira-Neto et al.(10). During the trial period, we analyzed a total of 187 parturitions, of which 85 male and 102 female calves were born with an average birth weight of $41.73 \mathrm{~kg}$. No differences in birth weight were found between the calves born in spring-summer and autumn-winter $(P=0.232)$, probably because crossbred animals are more tolerant to high temperatures predominant in tropical regions. Calf sex was not associated with birth weight $(P=0.720)$; however, the cows with below-average gestation length calved lighter calves $(P=0.001)$, and this might be because of incomplete fetal calf development in shorter gestation periods (Table 1).

Table 1. Effect of the calving season, calf sex, and gestation length on the weight of crossbred dairy calves at a dairy farm in Alto Paranaíba, Minas Gerais State, Brazil

\begin{tabular}{lcc}
\hline Parameters & Calf weight $(\mathbf{k g})$ & $P$-value \\
\hline Season of the year at birth & & \\
Spring-summer (99) & $41.42 \pm 4.445$ & 0.232 \\
Autumn-winter (88) & $42.07 \pm 4.381$ & \\
\hline Calf sex & $41.58 \pm 3.924$ & 0.720 \\
Female (102) & $41.91 \pm 4.958$ & \\
Male (85) & & \\
\hline Gestation length & & \\
Below average (89) & $40.29 \pm 3.935$ & 0.001 \\
Above average (98) & $43.03 \pm 4.441$ & \\
\hline
\end{tabular}

* Average gestation length was 274.4 days.

It was expected that the parturitions that occurred in spring-summer produced lighter calves despite of heat stress consequences. Tao et al.(11) and Monteiro et al. ${ }^{(12)}$ reported that the calves born from the cows submitted to heat stress during the dry period showed lower weight at birth compared to the calves born from the cows in thermal comfort. Pregnant cows exposed to heat stress had reduced uterine blood flow, which caused retardation in fetal growth ${ }^{(13)}$, lower placental weight ${ }^{(14)}$ and lower calf birth weight ${ }^{(11)}$. However, these effects were not observed in the present study.

Kertz et al. ${ }^{(15)}$ recorded, besides other variables, calf body weight and sex at parturition in Holstein cows and heifers for 5 years. The authors reported an average calf birth weight 
of $41.4 \mathrm{~kg}$, similar to the result obtained in the present study, and male calves were $8.5 \%$ heavier than female calves, unlike the present study. The physiological explanation for male calves born heavier than female calves is that they produce androgenic hormones. Male fetal calf starts producing significant amount of testosterone by 45 days of gestation, and serum testosterone concentrations rise through 70 days. The presence of androgen receptors in muscle cells during fetal development results in enhanced muscle tissue growth and birth weight differences between the sexes ${ }^{(16)}$.

A positive correlation ranging from low to moderate exists between gestation length and calf birth weight in cattle. It is known that longer gestation periods allow for additional fetal growth, but there is a limit for this, once the magnitude in increase birth weight by prolonging gestation length is slight ${ }^{(16)}$. According to Holland and Odde, calf birth weight is not a function of gestation length ${ }^{(16)}$. Johanson and Berger ${ }^{(17)}$ demonstrated a linear and positive relationship between calf birth weight and perinatal mortality, implying that longer gestation produces heavier calves with increased risk of mortality close to birth.

In the present study, RP incidence was 36.89\% (69/187). According to the results of previous studies, RP incidence varied between 12.8 to $15.7 \%(18-21)$ for Holstein and Girolando dairy cows. In disagreement with the expected results, the crossbred dairy cows showed a high incidence of RP, regardless the season of the year. Crossbred animals are usually more adapted to hot and humid environmental conditions, predominant in tropical regions and are less prone to develop RP compared with purebred dairy cows.

The season of the year at calving did not affect RP incidence $(P=0.245)$ (Table 2). Rezende et al. ${ }^{(20)}$ evaluated Holstein cows managed in a free stall system in Alto Paranaiba region and reported no differences in RP incidence between different seasons. Buso et al.(21) also demonstrated that the calving season did not affect the incidence of RP of crossbred dairy cows. On the other hand, Nobre et al..(19) and Larson et al.(22) reported that the incidence of RP seemed to vary according to the season. Fernandes et al.(18) evaluated Holstein and Girolando dairy cows and found a higher RP incidence during the hottest periods of the year. Similarly, Muller and Owens ${ }^{(14)}$ reported differences in RP incidence between the winter and spring-summer seasons over a 5-year period in northern USA. Thus, these differences found among studies might be due to the differences in management practices applied by each farm, dairy cow breeds, environmental conditions, and other factors.

According to Nobre et al.(19), the rainy season elevates the environmental challenge for cows and predisposes them to the occurrence of RP. The region where the trial was conducted usually has high temperature and humidity during the spring-summer season because it is the rainiest period of the year, and this climate characteristic coincides with a challenging period for dairy cows, substantially increasing their risk of infection. However, a higher RP incidence was verified during both seasons.

In the present study, calf sex did not influence RP incidence $(P=0.332)$, which is in accordance with the findings of Muller and Owens ${ }^{(14)}$ who verified no differences of calf sex on RP incidence. Santos ${ }^{(23)}$ observed that calf sex did not affect the length of retained placental membranes and the percentage of cows with RP within 8 and 12 
hours after calf expulsion. Grohn and Rajala-Shultz(24) and Ettema and Santos ${ }^{(25)}$ reported that primiparous cows that calved female calves had less dystocia than cows those who calved male calves because male calves, owing to their greater size and weight at birth, increase the risk of dystocia which, in turn, is a risk factor for RP. Bell and Roberts(6) reported that male and oversize calves are associated with calving assistance and RP occurrence and are both considered as predisposing factors for uterine infections.

Table 2. Effects of calving season, calf sex, calf weight, and gestation length on the incidence of retained placenta in crossbred dairy cows at a dairy farm in Alto Paranaíba region, Minas Gerais State, Brazil

\begin{tabular}{lcc}
\hline Parameters & Incidence of retained placenta (\%) & P-value \\
\hline $\begin{array}{l}\text { Season of the year at } \\
\text { calving }\end{array}$ & & \\
$\begin{array}{l}\text { Spring-summer (99) } \\
\text { Autumn-winter (88) }\end{array}$ & 42.42 & \\
\hline Calf sex & 30.68 & 0.245 \\
Female (102) & 33.33 & 0.332 \\
Male (85) & 41.18 & \\
\hline Calf weight & & \\
Below average (85) & 51.76 & 0.005 \\
Above average (102) & 24.51 & \\
\hline Gestation length & & \\
Below average (89) & 49.44 & 0.008 \\
Above average (98) & 25.51 & \\
\hline
\end{tabular}

\# Average birth weight of the calves was $41.73 \mathrm{~kg}$.

* Average gestation length was 274.4 days.

The cows that calved calves with below-average birth weight $(41.73 \mathrm{~kg}$ ) and presented shorter gestation length ( $<274.4$ days) showed higher RP incidence compared to the cows with above-average gestation length (Table 2). This result could be attributed to the failure of placentomes to mature, which, in turn, might have led to the retention of the fetal membranes. Similar to our results, Vieira-Neto et al. ${ }^{(10)}$ reported that primiparous Holstein cows with shorter gestation lengths (between 256 and 269 days) had greater incidence of RP, which was true for multiparous Holstein cows with short or long gestation length. The gestation length is affected by several factors, including genetic factors, calf sex, single or twin pregnancies, cow age, and calving season ${ }^{(26)}$. It increases linearly as the number of lactations increases. It was reported that heat stress during the last 6 weeks of gestation reduced the gestation period of cows by 3 to 4 days compared to the cows subjected to controlled temperature and humidity ${ }^{(27)}$. McClintock et al. ${ }^{(28)}$ reported that a shorter gestation period was associated with high 
summer temperatures. Shorter gestation length was also associated with an increase in the incidence of uterine infections in dairy $\operatorname{cows}^{(6)}$. More studies may be necessary to clearly understand the specific causes and factors related to short gestation length as well as to develop strategies to prevent its occurrence in dairy cows.

\section{Conclusion}

Crossbred lactating dairy cows that calve single viable calves following a short gestation period compromise offspring birth weight and are more susceptible to develop RP in the postpartum period.

\section{References}

1. Bernardi F, Possa MG, Pinto NA, Weber C, Oberlender G. Prevalence and economic impact of retained placenta in dairy herds from family farms in southwest Paraná, Brazil.Vet. E Zootec. 2016; 23(3):453-464.

2. Fernandes CAC, Carvalho RJ. Impacto da retenção de placenta sobre a performance reprodutiva de vacas leiteiras. [Impact of retained placenta on the reproductive performance of dairy cows]. Revista Brasileira de Reprodução Animal. 2001; 25(1):26-30. Portuguese

3. Malard PF, Barreto Filho JB, Santos RL, Marques Junior AP. Proporção volumétrica dos componentes estruturais da placenta de vacas zebu ao longo da gestação. [Volumetric ratio of the structural components of the placenta of zebu cows during gestation]. Arq. Bras. Med. Vet. Zootec. 1996; 48:553-558. Portuguese

4. Grunert E, Birgel EH, Vale WG. Patologia e clínica da reprodução dos animais mamíferos domésticos. [Pathology and clinical reproduction of domestic mammals]. 1st ed. São Paulo: Editora Varela, 2005. 479486p. Portuguese

5. Sheldon IM, Dobson H. Postpartum uterine health in cattle. Anim. Reprod. Sci. 2004; 82-83:295-306.

6. Bell MJ, Roberts DJ. The impact of uterine infection on a dairy cow's performance. Theriogenology. 2007; 68(7):1074-1079.

7. Gunay A, Gunay U, Orman A. Effects of retained placenta on the fertility in treated dairy cows. Bulgarian Journal of Agricultural Science. 2011; 17:126-131.

8. LeBlanc SJ. Postpartum uterine disease and dairy herd reproductive performance: a review. The Veterinary Journal. 2008; 176:102-114.

9. Sheldon IM, Cronin J, Goetze L, Donofrio G, Schubert HJ. Defining postpartum uterine disease and the mechanisms of infection and immunity in the female reproductive tract in cattle. Reproduction in Domestic Animals. 2009; 44:1-9.

10. Vieira-Neto A, Galvão KN, Thatcher WW, Santos JEP. Association among gestation length and health, production, and reproduction in Holstein cows and implications for their offspring. J. Dairy Sci. 2016; 100:3166-3181.

11. Tao S, Monteiro AP, Thompson IM, Hayen MJ, Dahl GE. Effect of late gestation maternal heat stress on growth and immune function of dairy calves. J. Dairy Sci. 2012; 95:7128-7136.

12. Monteiro APA, Tao S, Thompson IM, Dahl GE. Effect of heat stress during late gestation on immune function and growth performance of calves: Isolation of altered colostral and calf factors. J. Dairy Sci. $2014 ; 97: 6426-6439$.

13. Oakes GK, Walker AM, Ehrenkranz RA, Cefalo RC, Chez RA. Uteroplacental Blood Flow During 
Influence of gestation length, seasonality, and calf sex on birth weight and placental retention in crossbred dairy cows Rezende, E.V. et al.

Hyperthermia With And Without Respiratory Alkalosis. J. Appl. Physiol. 1976; 41:197-201.

14. Muller LD, Owens MJ. Factors associated with the incidence of retained placentas. Journal of Dairy Science. 1974; 57:725-728.

15. Kertz AF, Reutzel LF, Barton BA, Ely RL. Body weight, body condition score, and wither height of prepartum Holstein cows and birth weight and sex of calves by parity: a database and summary. J. Dairy Sci. 1997; 80:525-529.

16. Holland MD, Odde KG. Factors affecting calf birth weight: a review. Theriogenology.1992; 38(5):769798.

17. Johanson JM, Berger PJ. Birth weight as a predictor of calving ease and perinatal mortality in Holstein cattle. J. Dairy Sci. 2003; 86(11):3745-3755.

18. Fernandes CAC, Palhão MP, Ribeiro JR, Viana JHM, Gioso MM, Figueiredo ACS, Oba E, Costa DS. Associação entre oxitetraciclina e cloprostenol no tratamento de vacas leiteiras com retenção de placenta. [Association between oxytetracycline and cloprostenol in the treatment of retained placenta in dairy cows]. Revista Brasileira de Ciência Veterinária. 2012; 19(3):178-182. Portuguese

19. Nobre MM, Coelho SG, Haddad JPA, Campos EF, Lana AMQ, Reis RB, Saturnino HM. Avaliação da incidência e fatores de risco da retenção de placenta em vacas mestiças leiteiras. [Evaluation of the rate and risk factors for retained placenta in crossbred dairy cows]. Arquivo Brasileiro de Medicina Veterinária e Zootecnia. 2012; 64:101-107. Portuguese

20. Rezende EV, Campos CC, Santos RM. Incidência da retenção de placenta e as consequências na produção de leite e na eficiência reprodutiva de vacas holandesas. [Rate of retained placenta and the effects on milk production and reproductive efficiency of Dutch cows]. Acta Scientiae Veterinariae. 2013; 41:1170. Portuguese

21. Buso RR, Campos CC, Santos TR, Saut JPE, Santos RM. Retained placenta and subclinical endometritis: prevalence and correlation with the reproductive performance of crossbred dairy cows. Pesquisa Veterinária Brasileira, 2018; 38: 1-5.

22. Larson LL, Ishak MA, Owen FG, Erickson ED, Lowry SR. Relationship of physiological factors to placental retention in dairy cattle. Animal Reproduction Science. 1985; 9:31-43.

23. Santos RM, Vasconselos JLM, Souza AH, Meneghetti M, Junior FN. Efeito da aplicação de prostaglandina (PGF2a) no pós-parto imediato sobre a incidência de retenção de placenta em vacas de leite. [Effect of the application of prostaglandin (PGF2a) in the immediate postpartum on the rate of retained placenta in dairy cows]. Arq.Bras. Med. Vet. Zootec. 2002; 54(1). Portuguese

24. Grohn YT, Rajala-Schultz PJ. Epidemiology of reproductive performance in dairy cows. Animal Reproduction Science. 2000; 60-61:605-614.

25. Ettema JF, Santos JEP. Impact of age at calving on lactation, reproduction, health, and income in firstparity Holsteins on commercial farms. Journal of Dairy Science. 2004; 87:2730-2742.

26. Silva HM, Wilcox CJ, Thatcher WW, Becker RB, Morse D. Factors affecting days open, gestation length, and calving interval in Florida dairy cattle. J. Dairy Sci. 1992; 75:288-293.

27. Tao S, Dahl GE. Invited review: Heat stress effects during late gestation on dry cows and their calves. J. Dairy Sci. 2013; 96:4079-4093.

28. Mcclintock S, Beard K, Gilmour A, Goddard M. Relationships between calving traits in heifers and mature cows in Australia. Interbull Bull. 2006; 31:102-106. 